\title{
Communication
}

\section{Brönsted acidic ionic liquid catalyzed synthesis of benzo $[a]$ carbazole from renewable acetol and 2-phenylindoles in a biphasic system}

\author{
Minghao Li ${ }^{\mathrm{a}}$, Fengtian $\mathrm{Wu}^{\mathrm{a}}$, Yanlong $\mathrm{Gu}$ a,b,* \\ a Key Laboratory of Material Chemistry for Energy Conversion and Storage, Ministry of Education, Hubei Key Laboratory of Material Chemistry and \\ Service Failure, School of Chemistry and Chemical Engineering, Huazhong University of Science and Technology, Wuhan 430074, Hubei, China \\ b State Key Laboratory for Oxo Synthesis and Selective Oxidation, Lanzhou Institute of Chemical Physics, Chinese Academy of Sciences, Lanzhou 730000, \\ Gansu, China
}

\section{A R T I C L E I N F O}

\section{Article history:}

Received 13 March 2019

Accepted 3 April 2019

Published 5 August 2019

\section{Keywords:}

Benzo[a]carbazole

Brönsted acid ionic liquid

Bio-renewable acetol

2-Phenylindole

\begin{abstract}
A B S T R A C T
An efficient metal-free strategy for the synthesis of pharmaceutically relevant benzo[ $a]$ carbazoles from the derivatives of readily available 2-phenylindole and bio-renewable acetol in an aqueous biphasic system was developed. This protocol employed a sulfone-containing Brönsted acidic ionic liquid as the catalyst, which could be used for five times without a noticeable decrease in its activity and selectivity. Various substituted 2-phenylindoles and $\alpha$-hydroxyketones participated in the reaction smoothly, with water as the sole byproduct. Mechanistically, the reaction involved the conventional carbon-nucleophile-induced Heyns-type rearrangement and downstream intramolecular olefination.
\end{abstract}

(C) 2019, Dalian Institute of Chemical Physics, Chinese Academy of Sciences. Published by Elsevier B.V. All rights reserved.
The realization of simple and green synthetic procedures is an important goal in organic synthesis [1,2]. In this context, tandem reactions have been widely adopted to combat the tedious operational procedure associated with multistep synthesis [3-8]. While many acid-catalyzed tandem reactions have been developed $[9,10]$, the ever-increasing demand for novel molecules with biological and material uses and the laborious process of the conventional stepwise synthesis have resulted in the continuous search for developing simple and efficient tandem reactions.

Incorporation of renewable chemicals into heterocycles constitute one of the important ways to valorize biomass, which also follow the principles of green chemistry [11-14].
Acetol can be readily produced through the staged pyrolysis of biomass at low temperatures of $200-300{ }^{\circ} \mathrm{C}$ [15]. Although some acetol-derived heterocycles including pyrazine [16], oxazoline [17], furan [18], and quinoxaline [19] have been reported, incorporating acetol into novel heterocycles is still desired.

The synthesis of benzo[a]carbazoles has garnered much attention due to their wide application in medicinal chemistry (compounds A and B in Scheme 1) and photographic materials (compound C in Scheme 1) [20-24]. Numerous synthetic methodologies have been developed to construct this privileged core material in the past few decades [25-38]. Among those, protocols with 2-phenylindole as the starting material have recently emerged as one of the most appealing methods

\footnotetext{
* Corresponding author. Tel: +86-27-87543032; Fax: +86-27-87543632; E-mail: klgyl@hust.edu.cn

This work was supported by the National Natural Science Foundation of China $(21761132014,21872060)$, the Fundamental Research Funds for the Central Universities of China (2016YXZD033), the Fundamental Research Funds for the Central Universities (2019kfyXJJS072), and Opening fund of Hubei Key Laboratory of Material Chemistry and Service Failure (2017MCF01K).

DOI: S1872-2067(19)63370-X | http://www.sciencedirect.com/science/journal/18722067 | Chin. J. Catal., Vol. 40, No. 8, August 2019
} 


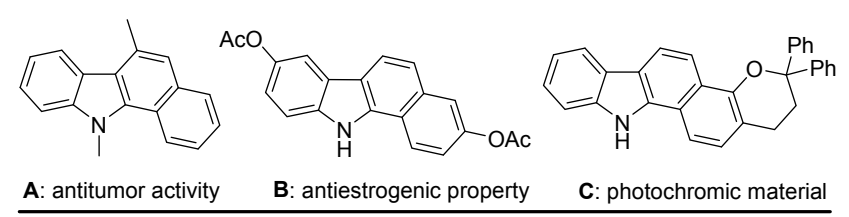

(2)
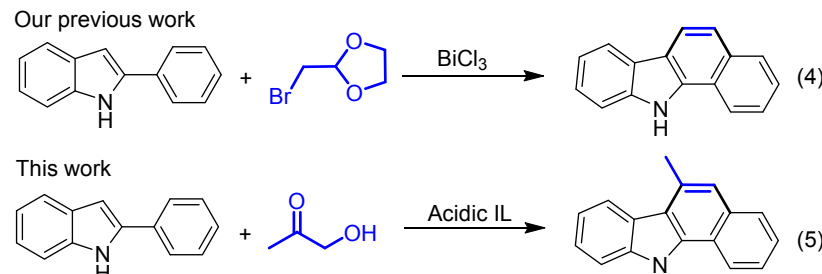

Scheme 1. Benzo $[a]$ carbazole analogues and the approaches for their synthesis from 2-phenylindole.

since elaborate design and multistep synthesis of the starting material is avoided. However, until now there have been only four approaches to implement this transformation as shown in Scheme 1: (1) In(ONf)3-catalyzed [4+2] benzannulation with propargyl ethers (Eq. (1)) [39,40], (2) palladium-catalyzed aerobic-oxidative cycloaromatization with internal alkynes (Eq. (2)) [41], (3) Rh(III)-catalyzed cascade reactions with $\alpha$-diazo carbonyl compounds (Eq. (3)) [42,43], and (4) $\mathrm{BiCl}_{3}$-catalyzed benzannulation with $\alpha$-bromoacetaldehyde (Eq. (4)) [44]. Considering the versatility of benzo[ $[a]$ carbazoles, the development of novel methods, such as metal-free methods, to synthesize this structural motif from readily available starting materials are in demand. Herein, we report for the first time, the Brönsted acidic ionic liquid (BAIL)-catalyzed synthesis of benzo[a]carbazole from 2-phenylindole (Eq. (5), Scheme 1) in a biphasic system with the following features: (1) renewable counter-reagent, (2) recyclable catalyst, (3) high atom economy (with water as the sole byproduct), and (4) high chemoselectivity.

We commenced our study with acetol and 2-phenylindole in nitroethane at $95^{\circ} \mathrm{C}$. As shown in Table 1, no reaction occurred by employing weak acid catalysts such as $\mathrm{LiBr}$ and $\mathrm{H}_{3} \mathrm{BO}_{3}$ (Table 1, entries 1 and 2). $\mathrm{ZnCl}_{2}$ did not catalyze the reaction either (Table 1, entry 3). However, the product (3a) was formed, albeit in a very low yield, when $\mathrm{BiCl}_{3}$ catalyst was used (Table 1 , entry 4). Strong acids such as $\operatorname{Al}(\mathrm{OTf})_{3}, \operatorname{Sc}(\mathrm{OTf})_{3}, \mathrm{Cu}(\mathrm{OTf})_{2}$, PTSA and TfOH were also examined for their catalytic activity (Table 1, entries 5-9). However, the maximum yield reached only $37 \%$ with TfOH (Table 1, entry 9). We then attempted to examine the change in the yield using organic solvents such as
Table 1

Reaction of 1a and 2a under homogeneous conditions.

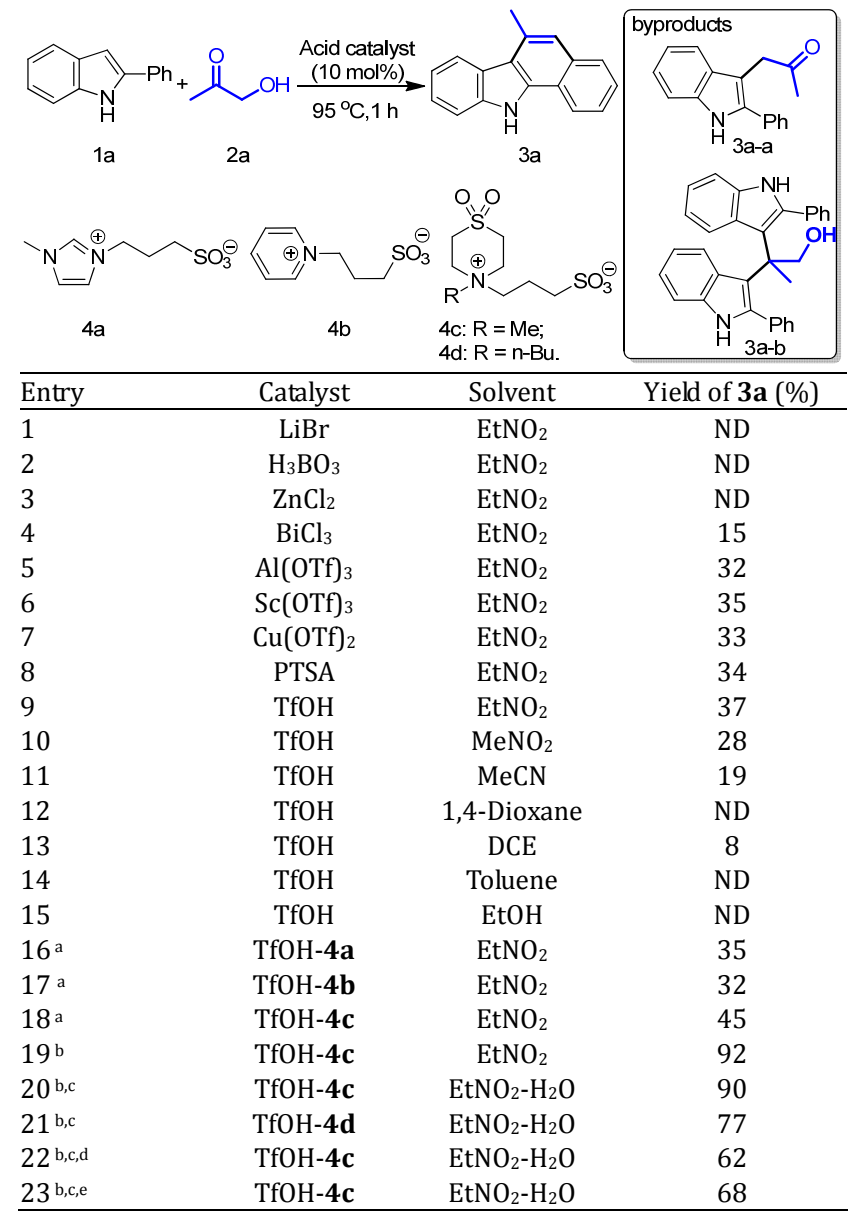

Reaction conditions: 1a $(0.3 \mathrm{mmol}), \mathbf{2 a}(0.45 \mathrm{mmol}), \mathrm{TfOH}(10 \mathrm{~mol} \%)$, solvent $(1.0 \mathrm{~mL})$, zwitterion $\left(0.25 \mathrm{~g}\right.$, if mentioned) at $95^{\circ} \mathrm{C}$ for $1 \mathrm{~h}$, isolated yield. a 1.0 equivalent of zwitterion based on TfOH. ${ }^{\mathrm{b}} 20.0$ equivalents $(250.0 \mathrm{mg}$ ) of zwitterion based on TfOH. c 8.0 equivalents of water based on zwitterion. ${ }^{\mathrm{d}} 60^{\circ} \mathrm{C}$. e $30 \mathrm{~min}$.

nitromethane, acetonitrile, 1,4-dioxane, and 1,2-dichloroethane, but there was no increase in the yield (Table 1, entries 10-13). The non-polar solvent, toluene, and the protic solvent, ethanol, also failed to improve the yield (Table 1, entries 14 and 15). The reaction also gave two byproducts, 3a-a and 3a-b. Thus, in order to improve reaction selectivity, we performed the reaction under biphasic conditions. Unfortunately, neither the aqueous biphasic systems (Table S1) nor the non-aqueous biphasic systems (Table S2) proved successful in enhancing the yield of 3a. BAILs have been widely used in organic catalysis [45-48]. Thus, some triflic acid-derived BAILs were examined in this study. Considering the hygroscopic property of BAILs, they were prepared in situ by mixing the corresponding zwitterions with TfOH. The imidazolium- (4a) and pyridinium-type (4b) BAILs showed similar catalytic activity as TfOH (Table 1, entries 16 and 17). However, in the presence of the ammonium-type (4c) BAIL, 3a was obtained in $45 \%$ yield (Table 1, entry 18). In addition, the yield of $\mathbf{3 a}$ increased with an excess amount of $\mathbf{4 c}$, based on triflic acid (Table S3). When 20 equivalents of $\mathbf{4} \mathbf{c}$ were used, 3a was obtained in $92 \%$ 
yield (Table 1, entry 19). Since 3a was formed through a dehydration process, 8 equivalents of water, based on $\mathbf{4 c}$, was added to check whether the excess amount of zwitterion played the role of a reservoir. However, the reaction yield did not change significantly (Table 1, entry 20). With 8 equivalents of water, 4c was completely dissolved in the aqueous phase and a biphasic system was formed in conjunction with nitroethane (Fig. S1). After the reaction, the TfOH remained in the aqueous phase and both the acid and $\mathbf{4 c}$ could be reused for five times (Fig. 1). Nitroethane was necessary for this reaction and replacement of nitroethane with other organic solvents resulted in reduced yields (Table S4). The ability of the amphiphilic zwitterion (4c vs 4d), reaction temperature, and time also affected the yield (Table 1, entries 21-23). Thus, the optimized conditions for the reaction was obtained with $\mathrm{TfOH}(10 \mathrm{~mol} \%), 4 \mathrm{c}(200 \mathrm{~mol} \%)$, and $\mathrm{H}_{2} \mathrm{O}(1600 \mathrm{~mol} \%)$ in $\mathrm{EtNO}_{2}(1.0 \mathrm{~mL})$ at $95^{\circ} \mathrm{C}$ for $1 \mathrm{~h}$.

The scope of the substrates was then probed under the optimized conditions (Fig. 2). An apparent electronic effect could be observed by varying the substituents on the indole ring of 2-phenylindole. 2-phenylindoles with an electron-donating substituent at the C5-position produced the corresponding benzo $[a]$ carbazoles in excellent yields (3b and $\mathbf{3 c}$ ). The congeners with weak electron-withdrawing substituents such as 5-fluoro-2-phenylindole and 5-chloro-2-phenylindole, only gave a moderate yield. However, by increasing the reaction time, the corresponding benzo[a]carbazoles, $\mathbf{3 d}$ and $\mathbf{3 e}$, were obtained in $72 \%$ and $75 \%$ yields, respectively. A similar tendency was also observed by varying the substituents at the benzene ring of 2 -phenylindole $(\mathbf{3 g}, \mathbf{3 h}$, and $\mathbf{3 i}$ vs $\mathbf{3} \mathbf{j})$. The $\mathrm{N}$-substituted 2-phenylindole reacted readily with acetol to produce 3k in $86 \%$ yield, which reportedly exhibits pronounced antitumor activity against leukemia, renal cancer, colon cancer, and malignant melanoma cell lines [23]. Two 2-heteroarylindoles, 2-(furan-2-yl)-1H-indole, and 2-(thiophen-2-yl)- $1 H$-indole, were also used in this reaction, with which the target products, $\mathbf{3} \mathbf{l}$ and $\mathbf{3 m}$, were isolated in $76 \%$ and $75 \%$ yields, respectively.

To understand the limitation of this protocol we also examined the $\alpha$-hydroxyketones (Scheme 2). $\alpha$-Hydroxyacetophenone reacted smoothly with 2-phenylindole to generate the desired product (5a) in moder-

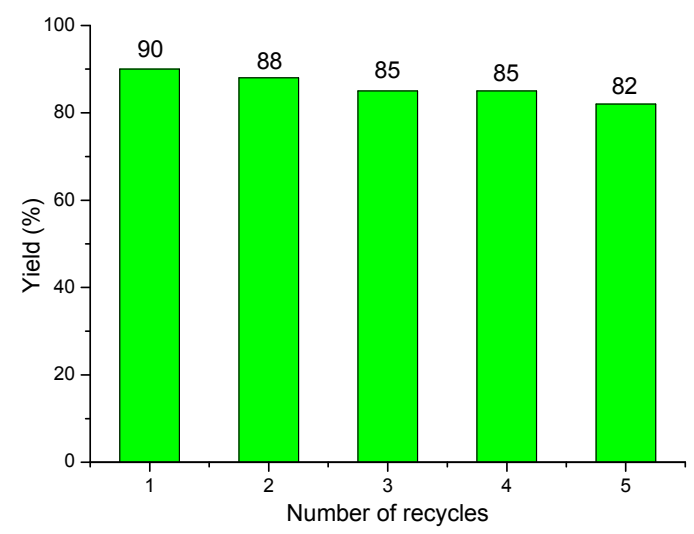

Fig. 1. Recyclability of the catalyst present in the aqueous phase.

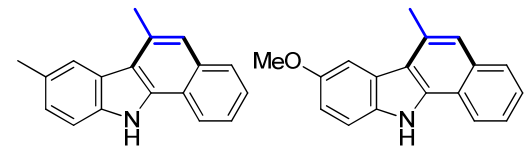

3b $89 \%$, 45 min 3c $90 \%, 50 \mathrm{~min}$<smiles>Cc1cc2ccccc2c2[nH]c3ccc(Cl)cc3c12</smiles><smiles>Cc1ccc2c(c1)cc(C)c1c3ccccc3[nH]c21</smiles>
3f $92 \%, 45 \mathrm{~min}$

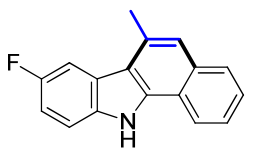

3d $72 \%, 2 \mathrm{~h}$

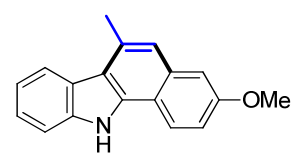

3g $92 \%, 50$ min<smiles>Cc1cc2cc(C(C)(C)C)ccc2c2[nH]c3ccccc3c12</smiles>

3h $82 \%, 50 \mathrm{~min}$

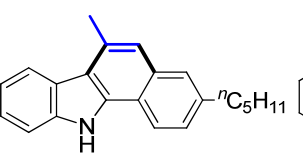

3i $80 \%, 55 \mathrm{~min}$<smiles>Cc1cc2cc(Br)ccc2c2[nH]c3ccccc3c12</smiles>

3j $70 \%, 2 \mathrm{~h}$

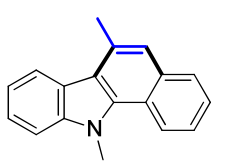

3k $86 \%, 1 \mathrm{~h}$

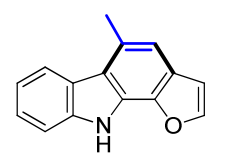

31 $76 \%, 40 \mathrm{~min}$

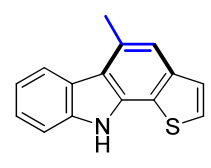

$3 \mathrm{~m} 75 \%, 40 \mathrm{~min}$

Fig. 2. Substrate scope for 2-phenylindole.

ate yield. 2,2-Diethoxyethanol as a masked glycolaldehyde [49], which is a biomass-derived chemical compound synthesized from cellulose or glucose, formed $\mathbf{5 b}$ in $80 \%$ yield. However, substitutions at the alpha position of the hydroxyl group seemed to be unfavorable since no expected products were obtained with 3-hydroxy-2-butanone and benzoin (5c and 5d). However, $\alpha$-methoxyacetone gave the same product as acetol in $89 \%$ yield.

A proposed mechanism for this reaction is depicted in Fig. 3. The reaction was triggered by the Brönsted acid mediated nucleophilic addition of indole to ketone [50,51], followed by dehydrogenation to generate intermediate I. The carbocation intermediate I resonates with the iminium intermediate II and the oxonium intermediate III. Michael addition of intermediate II to 1a gave the byproduct $\mathbf{3 a - b}$ while the isomerization of intermediate III via 2-phenylindole migration [52-54] followed by deprotonation furnished the byproduct 3a-a. We believed that the main product 3a was formed through the intermediate V, which was generated from intermediate I either by dehydration followed by protonation or hydride migration. Mechanistically, however, the formation of $\mathbf{3 a}$ directly from intermediate IV via $6 \pi$-electrocyclization followed by dehydration could not be ruled out. The existence of many electrophiles (intermediates I-IV, 3a-a, and 1a) and nucleophiles (1a and 2a) simulta-

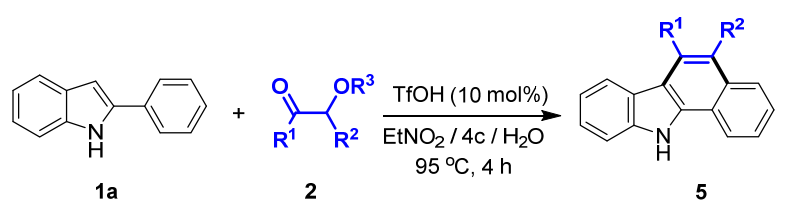

5a, $R^{1}=P h, R^{2}=H, R^{3}=H, 50 \%$; 5b, $R^{1}=H, R^{2}=H, R^{3}=H, 80 \%$; 5c, $R^{1}=M e, R^{2}=M e, R^{3}=H, 0 \%$; 5d, $R^{1}=P h, R^{2}=P h, R^{3}=H, 0 \%$. 3a, $R^{1}=M e, R^{2}=H, R^{3}=M e, 89 \%$

Scheme 2. Substrate scope for $\alpha$-hydroxyacetones. 


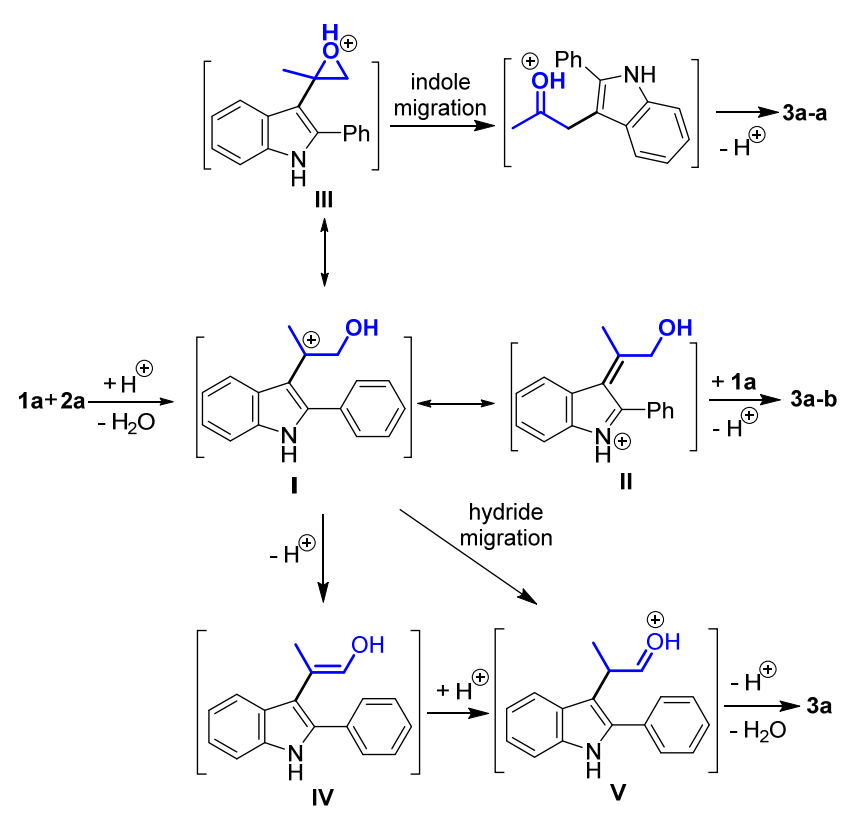

Fig. 3. A proposed mechanism involving a carbocation intermediate.

neously was a challenge to controlling the reaction selectivity. The sulfone group of $\mathbf{4 c}$ was assumed to play an important role in stabilizing the carbocation intermediate $\mathbf{I}$ and thus, favor the formation of $\mathbf{3 a}$.

Inspired by intermediate $\mathbf{V}$, we envisioned that by introducing a nucleophilic site in the structure of -hydroxyketone and using a simple nucleophile, a similar tandem reaction could be possible. Thus, $\mathbf{2 b}$ and $\mathbf{2 c}$ were synthesized and subject to the reaction with $N$-methylindole (Scheme 3). Interestingly, the desired 1,2-dihydronaphthalene derivative 6a was obtained with $\mathbf{2 b}$ but a carbazole $\mathbf{6 b}$ was formed with $\mathbf{2 c}$, indicating the facile aerobic auto-oxidation of 4,9-dihydrocarbazole.

In conclusion, an expeditious synthesis of benzo[a]carbazole from readily available 2-phenylindoles and bio-renewable acetol catalyzed by BAIL in a biphasic system, with the aqueous solution of ammonium zwitterions and nitroethane, was accomplished. This reaction proceeded smoothly without the need for costly or toxic metal-based catalysts. The catalytic system could be used for five times without a significant loss in its catalytic activity. We postulate that this novel route has a

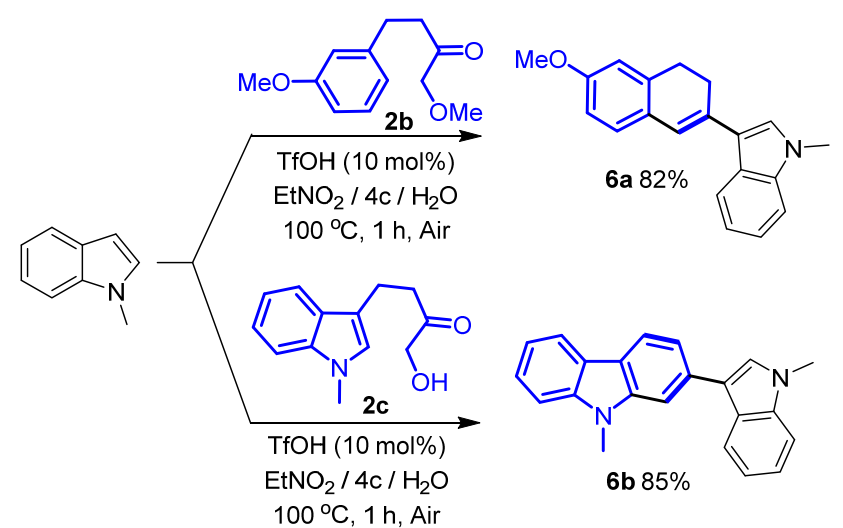

Scheme 3. Carbon-nucleophile-induced intramolecular cyclizations. great potential for the synthesis of pharmaceutically relevant benzo[a]carbazole derivatives.

\section{Notes}

The authors declare no competing financial interest.

\section{Acknowledgment}

The Cooperative Innovation Center of Hubei province and the testing center of HUST are acknowledged.

\section{References}

[1] R. A. Sheldon, Chem. Soc. Rev., 2012, 41, 1437-1451.

[2] C. J. Li, B. M. Trost, Proc. Nat. Acad. Sci. USA, 2008, 105, 13197-13202.

[3] C. Grondal, M. Jeanty, D. Enders, Nat. Chem., 2010, 2, 167-178.

[4] H. Pellissier, Adv. Synth. Catal, 2012, 354, 237-294.

[5] L. F. Tietze, T. Kinzel, C. C. Brazel, Acc. Chem. Res., 2009, 42, 367-378.

[6] S. F. Mayer, W. Kroutil, K. Faber, Chem. Soc. Rev., 2001, 30, 332-339.

[7] Q. Liao, X. Yang, C. Xi, J. Org. Chem., 2014, 79, 8507-8515.

[8] L. J. Sebren, J. J. Devery, C. J. R. Stephenson, ACS Catal., 2014, 4, 703-716.

[9] J. Jiang, L.-Z. Gong, Bronsted acid-catalyzed cascade reactions, (Ed.) P.-F. Xu, W. Wang, Catal. Cascade React., 2014, 53-122.

[10] F. Lv, S. Liu, W. Hu, Asian J. Org. Chem., 2013, 2, 824-836.

[11] R.-J. van Putten, J. C. van der Waal, E. de Jong, C. B. Rasrendra, H. J. Heeres, J. G. de Vries, Chem. Rev., 2013, 113, 1499-1597.

[12] R. P. Bhusal, J. Sperry, Green Chem., 2016, 18, 2453-2459.

[13] Z. Li, X. Tang, Y. Jiang, M. Zuo, Y. Wang, W. Chen, X. Zeng, Y. Sun, L. Lin, Green Chem., 2016, 18, 2971-2975.

[14] B. Wozniak, Y. Li, S. Hinze, S. Tin, J. G. de Vries, Eur. J. Org. Chem., 2018, 2009-2012.

[15] D. E. Resasco, S. P. Crossley, Catal. Today, 2015, 257, 185-199.

[16] L. Song, M. Zheng, J. Pang, J. Sebastian, W. Wang, M. Qu, J. Zhao, X. Wang, T. Zhang, Green Chem., 2017, 19, 3515-3519.

[17] R. Pandya, R. Mane, C. V. Rode, Catal. Sci. Technol., 2018, 8, 2954-2965.

[18] A. Gangjee, X. Lin, R. L. Kisliuk, J. J. McGuire, J. Med. Chem., 2005, $48,7215-7222$.

[19] S. A. Raw, C. D. Wilfred, R. J. K. Taylor, Org. Biomol. Chem., 2004, 2, 788-796.

[20] Y.-Q. Wang, X.-H. Li, Q. He, Y. Chen, Y.-Y. Xie, J. Ding, Z.-H. Miao, C.-H. Yang, Eur. J. Med. Chem., 2011, 46, 5878-5884.

[21] A. Segall, H. Pappal, R. Casaubon, G. Martin, R. Bergoc, M. T. Pizzomol, Eur. J. Med. Chem., 1995, 30, 165-169.

[22] E. Von Angerer, J. Prekajac, J. Med. Chem., 1986, 29, 380-386.

[23] U. Pindur, T. Lemster, Recent Res. Dev. Org. Bioorg. Chem. 1997, 1, 33-54.

[24] M. M. Oliveira, M. A. Salvador, P. J. Coelho, L. M. Carvalho, Tetrahedron, 2005, 61, 1681-1691.

[25] C.-C. Chen, L.-Y. Chin, S.-C. Yang, M.-J. Wu, Org. Lett., 2010, 12, 5652-5655.

[26] K. Hirano, Y. Inaba, N. Takahashi, M. Shimano, S. Oishi, N. Fujii, H. Ohno, J. Org. Chem., 2011, 76, 1212-1227.

[27] C.-C. Chen, S.-C. Yang, M.-J. Wu, J. Org. Chem., 2011, 76, 10269-10274.

[28] R. Xie, Y. Ling, H. Fu, Chem. Commun., 2012, 48, 12210-12212. 


\title{
Graphical Abstract
}

Chin. J. Catal., 2019, 40: 1135-1140 doi: S1872-2067(19)63370-X

Brönsted acidic ionic liquid catalyzed synthesis of benzo[ $a]$ carbazole from renewable acetol and 2-phenylindoles in a biphasic system

Minghao Li, Fengtian Wu, Yanlong Gu*

Huazhong University of Science and Technology; Lanzhou Institute of

Chemical Physics, Chinese Academy of Sciences

An expeditious synthesis of benzo $[a]$ carbazole from readily available 2-phenylindoles and bio-renewable acetol catalyzed by a reusable Brönsted acidic ionic liquid is reported.

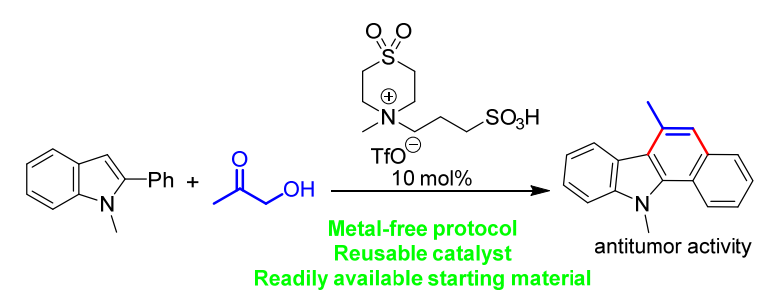

[29] X.-F. Xia, N. Wang, L.-L. Zhang, X.-R. Song, X.-Y. Liu, Y.-M. Liang, J. Org. Chem., 2012, 77, 9163-9170.

[30] T. Nanjo, S. Yamamoto, C. Tsukano, Y. Takemoto, Org. Lett., 2013, 15, 3754-3757.

[31] S. Protti, A. Palmieri, M. Petrini, M. Fagnoni, R. Ballini, A. Albinia, Adv. Synth. Catal., 2013, 355, 643-646.

[32] J. Yang, Q. Zhang, W. Zhang, W. Yu, RSC Adv., 2014, 4, 13704-13707.

[33] J.-R. Huang, L. Qin, Y.-Q. Zhu, Q. Songa, L. Dong, Chem. Commun., 2015, 51, 2844-2847.

[34] Y. Li, Z. Pang, T. Zhang, J. Yang, W. Yu, Tetrahedron, 2015, 71, 3351-3358.

[35] C.-W. Kuo, A. Konala, L. Lin, T.-T. Chiang, C.-Y. Huang, T.-H. Yang, V. Kavala, C.-F. Yao, Chem. Commun., 2016, 52, 7870-7873.

[36] I. T. Alt, B. Plietker, Angew. Chem. Int. Ed., 2016, 55, 1519-1522.

[37] L. Wu, G. Deng, Y. Liang, Org. Biomol. Chem., 2017, 15, 6808-6812.

[38] S. Parisien-Collette, C. Cruché, X. Abel-Snape, S. K. Collins, Green Chem., 2017, 19, 4798-4803.

[39] T. Tsuchimoto, H. Matsubayashi, M. Kaneko, E. Shirakawa, Y. Kawakami, Angew. Chem. Int. Ed., 2005, 44, 1336-1340.

[40] T. Tsuchimoto, H. Matsubayashi, M. Kaneko, Y. Nagase, T. Miyamura, E. Shirakawa, J. Am. Chem. Soc., 2008, 130, 15823-15835.

[41] Z. Shi, S. Ding, Y. Cui, N. Jiao, Angew. Chem., Int. Ed., 2009, 48, 7895-7898.
[42] Z. Zhang, K. Liu, X. Chen, S.-J. Su, Y. Deng, W. Zeng, RSC Adv., 2017, 7, 30554-30558.

[43] B. Li, B. Zhang, X. Zhang, X. Fan, Chem. Commun., 2017, 53, 1297-1300.

[44] F. Wu, W. Huang, L. Yi, J. Yang, Y. Gu, Adv. Synth. Catal., 2018, 360, 3318-3330.

[45] A. S. Amarasekara, Chem. Rev., 2016, 116, 6133-6183.

[46] C. Wu, L.-H. Lu, A. Z. Peng, G.-K. Jia, C. Peng, Z. Cao, Z. Tang, W.-M. He, X, Xu, Green Chem., 2018, 20, 3683-3688.

[47] L.-Y. Xie, S. Peng, L.-H. Lu, J. Hu, W.-H. Bao, F. Zeng, Z. Tang, X. Xu, W.-M. He, ACS Sustainable Chem. Eng., 2018, 6, 7989-7994.

[48] C. Wu, H.-J. Xiao, S.-W. Wang, M.-S. Tang, Z.-L. Tang, W. Xia, W.-F. Li, Z. Cao, W.-M. He, ACS Sustainable Chem. Eng., 2019, 7, 2169-2175.

[49] J. Xu, W. Huang, R. Bai, Y. Queneau, F. Jerome, Y. Gu, Green Chem., 2019, DOI: $10.1039 / C 8 G C 04000 A$.

[50] A. Taheri, C. Liu, B. Lai, C. Cheng, X. Pan, Y. Gu, Green Chem., 2014, 16, 3715-3719.

[51] S. Santra, A. Majee, A. Hajra, Tetrahedron Lett., 2011, 52, 3825-3827.

[52] R. Sanz, D. Miguel, F. Rodríguez, Angew. Chem. Int. Ed., 2008, 47, 7354-7357.

[53] G. Li, Y. Liu, J. Org. Chem., 2010, 75, 3526-3528.

[54] E. Álvarez, O. Nieto-Faza, C. Silva López, M. A. Fernández-Rodríguez, R. Sanz, Chem. Eur. J., 2015, 21, 12889-12893.

\section{Brönsted酸性离子液体催化 $\alpha$-羟基丙酮和2-苯基吲哚反应合成苯并 $[a]$ 咔唑}

\author{
李明浩 ${ }^{\mathrm{a}}$, 吴丰田 ${ }^{\mathrm{a}}$, 顾彦龙 ${ }^{\mathrm{a}, \mathrm{b},{ }^{*}}$ \\ a华中科技大学化学与化工学院, 能量转换与存储材料化学教育部重点实验室, \\ 材料化学与服役失效湖北省重点实验室, 湖北武汉 430074 \\ ${ }^{b}$ 中国科学院兰州化学与物理研究所羰基合成与选择氧化国家重点实验室, 甘肃兰州730000
}

摘要: 以生物质基平台化合物为原料合成含氧/氮杂环是实现生物质高值转化的重要途径. $\alpha$-羟基丙酮可通过生物质分段 热解获得, 是一种重要的生物质平台化合物. 尽管吡嗪, 恶唑啉, 呋喃, 和喹喔啉等 $\alpha$-羟基丙酮衍生化杂环化合物已有报道, 但将 $\alpha$-羟基丙酮转化为其它类型杂环仍具有很大的吸引力.

苯并 $[a]$ 咔唑化合物因其在医药和光学材料有广泛的应用而备受关注. 在过去二十年里, 开发出了许多合成苯并 $[a]$ 咔 唑的方法, 其中从简单易得的2-苯基吲哚出发, 构建苯并 $[a]$ 咔唑的方法最具吸引力, 但目前基于 2 -苯基吲哚合成苯并 $[a]$ 咔 唑的报道只有4例: (1) $\ln (\mathrm{OTf})_{3}$ 催化2-苯基吲哚和炔丙基醚的[4+2]反应; (2) Pd催化2-苯基吲哚与端炔氧化环化; (3) Rh(III) 催化2-苯基吲哚与 $\alpha$-重氮羰基化合物串联环化; (4) $\mathrm{BiCl}_{3}$ 催化2-苯基吲哚与 $\alpha$-溴乙缩醛苯环化反应. 考虑到苯并 $[a]$ 味唑化 
合物广泛的应用性, 从简单易得的原料出发, 发展新型的(例如非过渡金属催化)构建该类杂环的方法十分有必要.

本文报道了Brönsted酸性离子液体催化2-苯基吲哚和生物质基 $\alpha$-羟基丙酮的串联反应, 构建了一系列苯并 $[a]$ 咔唑化合 物. 首先通过对催化剂、溶剂和温度等参数的篮选, 确定了最佳反应条件为 $\mathbf{1 a}(0.3 \mathrm{mmol}), \mathbf{2 a}(0.45 \mathrm{mmol}), \mathrm{TfOH}(10 \mathrm{~mol} \%)$, $4 \mathbf{c}$ (2.0 equiv.), $\mathrm{H}_{2} \mathrm{O}$ (16.0 equiv.), 硝基乙烷 $(1.0 \mathrm{~mL}), 95^{\circ} \mathrm{C}, 1 \mathrm{~h}$. 在标准条件下, 给电子和拉电子基团取代的2-苯基弜哚都 可以很好地参与反应, 反应收率在 $70 \%-92 \%$ 之间, 相对富电子 2 -苯基吲哚, 较贫的 2 -苯基㓧哚反应活性更高, 2-呋喃或噻吩 吲哚也可以顺利参与反应. 在考察 $\alpha$-羟基丙酮同系物的反应活性时发现, $\alpha$-差基苯乙酮和 $\alpha$-羟基乙缩醛可以很好地参与反 应, 但在 $\alpha$-差基苯丙酮的 $\alpha$ 位引入取代基时, 目标产物不能有效生成. 值得说明的是, 在合成的苯并 $[a]$ 咔唑化合物中, $\mathbf{3 k}$ 具 有抗白血病和抗肿瘤活性, 另外反应中离子液体催化体系可以重复使用5次.

关键词: 苯并 $[a$ ]咔唑; Brönsted酸性离子液体; $\alpha$-羊基基丙酮; 2 -苯基吲哚; 串联反应

收稿日期: 2019-03-13. 接受日期: 2019-04-03. 出版日期: 2019-08-05.

*通讯联系人. 电话: (027)87543032; 传真: (027)87543632; 电子信箱: klgyl@hust.edu.cn

基金来源：国家自然科学基金(21761132014, 21872060); 中央高校基本科研业务费专项资金(2016YXZD033, 2019kfyXJJS072); 材 料化学与服役失效湖北省重点实验室开放基金(2017MCF01K).

本文的电子版全文由Elsevier出版社在ScienceDirect上出版(http://www.sciencedirect.com/science/journal/18722067). 